\title{
ÉTUDE D'UNE SUBSTITUTION PROGRESSIVE DU TOURTEAU DE SOJA PAR LA FÉVEROLE DÉCORTIQUÉE DANS UN RÉGIME POUR PORGS GHARGUTIERS
}

\author{
J. CASTAING et M. LEUILLET \\ Association générale des Producteurs de Maïs, \\ 1, Place Lestapis, \\ 64000 Pau, \\ Institut technique des Céréales et des Fourrages, \\ $8, A v$ du Président Wilson, \\ 75116 Paris

\section{RÉSUMÉ}

Nous avons entrepris un essai de substitution progressive de la féverole décortiquée au tourteau de soja 50 et aux céréales (blé/maïs) afin de déterminer un seuil maximum d'introduction de cette féverole traitée et les conditions économiques de son emploi dans les régimes pour porcs charcutiers. La féverole décortiquée a été introduite aux taux suivants :

$$
\text { 0-6- I 2-1 8-24-36 p. I }
$$

Pendant la durée totale de l'essai, on ne constate pas de différence significative entre les régimes en ce qui concerne la vitesse de croissance, la consommation et l'indice de consommation. Toutefois, le régime qui associe aux céréales la plus grande part de féverole décortiquée, tend à entraîner une augmentation de l'indice de consommation $(2,7$ p. 10o) et un ralentissement de croissance $(2,9$ p. IOo). En ce qui concerne les résultats à l'abattage, on ne note aucune différence significative sur l'ensemble des critères mesurés.

Le décorticage de la féverole permet de l'employer à un taux élevé dans les rations pour porcs sans modifier les performances zootechniques.

Cependant, afin d'obtenir un meilleur coût alimentaire par porc produit, il y a lieu de tenir compte de la freinte (20 p. Ioo du produit initial) et des frais de décorticage.

\section{SUMMARY}

PROGRESSIVE SUBSTITUTION OF SOYABEAN OIL-MEAL, BY SHEILLED HORSE-BEANS IN GROWING-FINISHING PIG DIETS

Progressive substitution of soyabean oil-meal 50 and of cereals (wheat/maize) by shelled horse-beans was attempted in order to determine the maximum incorporation level and economic utilization conditions in growing-finishing pig diets.

Shelled horse-beans were incorporated at the following levels :

$$
\text { 0-6-I 2-I 8-24-36 p. I00. }
$$


During the whole trial no significant differences were noted between the diets with respect to feed intake, growth rate and feed conversion ratio. However, the diets containing cereals + the largest amount of shelled horse-beans tended to increase the feed conversion ratio (2.7 p. IOO) and to slow down the growth rate $(2.9 \mathrm{p}$. Ioo). Concerning slaughter performances, the different criteria measured did not show any significant difference between the diets.

When shelled, horse beans can be used at a high level in pig diets without modifying the performances.

However, in order to obtain better feeding costs per pig produced, one must take into account the losses (20 p. roo of the initial product) and expenditures due to the shelling.

\title{
VALEUR ALIMENTAIRE DU « GLUTEN FEED " POUR LE PORC EN CROISSANCE-FINITION
}

\author{
D. BOURDON et Y. HENRY \\ Station de Recherches sur l'Élevage des Porcs, \\ Centre national de Recherches zootechniques, $I . N$. R. A., \\ 78350 Jouy en Josas
}

\section{RÉSUMÉ}

Quatre expériences sont réalisées en vue de préciser la valeur et les possibilités d'utilisation du "Gluten-Feed " comme source azotée complémentaire, dans des régimes à base de maïs, chez le Porc en croissance-finition.

Les résultats des deux premières expériences réalisées sur un total de 164 porcs, permettent de conclure à une utilisation optimale du "Gluten-Feed ", correctement supplémenté en lysine, au taux de 20 p. Ioo. Ainsi, il est possible d'assurer une substitution partielle des protéines de soja complémentaire d'environ 25 p. roo.

De même l'expérience 3 , réalisée en lots sur 96 porcs, démontre clairement qu'un mélange Gluten (40 p. roo de "Gluten-Feed " +60 p. Ioo de gluten de maïs) à 44 p. Ioo de protéines, correctement rééquilibré en lysine et utilisé au taux de 25 p. Ioo, peut assurer 75 p. Ioo de l'apport complémentaire de protéines.

La dernière expérience réalisée en digestibilité sur 16 porcs, a permis une estimation de la valeur énergétique du "Gluten Feed 》 à $2900 \mathrm{kcal}$ d'énergie digestible par kg de matière sèche, correspondant à un CUD apparent de l'énergie de 64 p. Ioo.

\section{SUMMARY}

\section{FEEDING VALUE OF « GLUTEN FEED " FOR GROWING-FINISHING PIGS}

Four experiments were made in order to determine the value and utilization possibilities of "Gluten Feed " as supplementary source of crude protein in diets based on maize given to growingfinishing pigs. 